\title{
H2 Receptor Antagonists versus Proton Pump Inhibitors in Patients on Dual Antiplatelet Therapy for Coronary Artery Disease: A Systematic Review
}

\author{
Aws Almufleh $^{a-c}$ F. Daniel Ramirez ${ }^{a, b, d}$ Derek So ${ }^{a, b}$ Michel Le May ${ }^{a, b}$ \\ Aun-Yeong Chong ${ }^{a, b}$ Nazi Torabi ${ }^{e}$ Benjamin Hibbert ${ }^{a}, b, f, g$ \\ ${ }^{a}$ Division of Cardiology, University of Ottawa Heart Institute, Ottawa, ON, Canada; ${ }^{b}$ CAPITAL Research Group, \\ University of Ottawa Heart Institute, Ottawa, ON, Canada; ' Department of Cardiac Sciences, King Saud University, \\ Riyadh, Saudi Arabia; ${ }^{d}$ School of Epidemiology and Public Health, University of Ottawa, Ottawa, ON, Canada; \\ eSchulich Library of Physical Sciences, Life Sciences, and Engineering, McGill University, Montreal, QC, Canada; \\ ${ }^{f}$ Vascular Biology and Experimental Medicine Laboratory, University of Ottawa Heart Institute, Ottawa, ON, Canada; \\ gDepartment of Cellular and Molecular Medicine, University of Ottawa, Ottawa, ON, Canada
}

\section{Keywords}

Gastrointestinal bleeding · Platelet reactivity •

Acute coronary syndrome

\begin{abstract}
Objectives: Mitigating the gastrointestinal (Gl) bleeding risks of dual antiplatelet therapy (DAPT) is a common clinical concern. While proton pump inhibitors (PPIs) remain the most effective therapy, their adverse events warrant considering alternatives, including Histamine 2 receptor antagonists (H2RAs). Methods: We searched for randomized controlled trials in MEDLINE, EMBASE, PubMed, and Cochrane Central Register of Controlled Trials, published from 1980 to 2016. After screening, 10 trials were eligible. We compared PPIs to H2RAs in patients on DAPT in terms of 2 clinical and one laboratory outcomes; Gl complications, major adverse cardiovascular events (MACE) and high on-treatment platelet reactivity (HTPR). Clinical and statistical inter-study heterogeneity was low for all 3 outcomes $\left(l^{2}=0 \%, p>0.05\right.$ for
\end{abstract}

\section{KARGER}

(c) 2018 S. Karger AG, Basel

E-Mail karger@karger.com

www.karger.com/crd all). Results: Fixed effects meta-analysis suggested that PPIs were superior to H2RAs in preventing Gl complications (OR $0.28,95 \% \mathrm{Cl} 0.17-0.48$ ) but with higher risk of HTPR (OR 1.28, 95\% Cl 1.030-1.60) though without a higher incidence of MACE (OR 0.99, 95\% CI 0.55-1.77). Conclusions: PPIs are superior to H2RAs for gastroprotection in patients on DAPT. However, PPIs are associated with HTPR, with no significant difference demonstrated in MACE. Based on currently available data, the use of PPIs may be warranted in selected patients on DAPT deemed at risk for Gl complications.

(c) 2018 S. Karger AG, Basel

\section{Introduction}

Dual antiplatelet therapy (DAPT, aspirin [ASA] plus a P2Y12 inhibitor) has been shown to improve cardiovascular outcomes in patients with acute coronary syndrome (ACS) and select patients with stable coronary artery disease (CAD) [1]. Though newer P2Y12 inhibitors, namely, 
ticagrelor and prasugrel, have been introduced, clopidogrel remains the most widely prescribed medicine likely due to its lower propensity to cause bleeding $[2,3]$. To mitigate the associated increase risk of gastrointestinal (GI) bleeding, proton pump inhibitors (PPIs) are commonly concurrently prescribed with DAPT for gastric protection. However, PPIs inhibit cytochrome P450, which is required for the activation of clopidogrel, a prodrug, into its active metabolite. In vitro studies have shown that PPIs differentially impact the platelet inhibitory effect of clopidogrel, and multiple observational studies have suggested that patients on DAPT and PPIs are at higher risk of cardiovascular events, possibly via this mechanism [4]. The Clopidogrel and the Optimization of GI Events Trial was a randomized controlled trial (RCT) that sought to test this hypothesis. However, the study was terminated early due to the loss of funding with a relatively short median follow-up (106 days) [5]. Given the possibility that PPIs have a clinically significant impact on the efficacy of DAPT, a Food and Drug Administration warning regarding concurrent clopidogrel and omeprazole therapy remains in effect [4].

In addition to potentially negating some of the benefits of DAPT, PPIs have been associated with numerous adverse conditions, including Clostridium difficile-associated diarrhea and community-acquired pneumonia $[6,7]$. The incremental benefit and cost effectiveness of PPIs have therefore been questioned when compared to other gastric acid suppressants, particularly Histamine 2 receptor antagonists (H2RAs) [8]. Prior observational studies have suggested that H2RAs are associated with a lower risk of rehospitalization post-ACS and of target vessel revascularization [4], possibly because H2RAs allow for greater platelet inhibition [9-11].

Currently, clinical guidelines recommend that clinicians balance the risks and benefits of prescribing gastric acid suppressive medications for patients with ACS or CAD on DAPT with risk factors for GI bleeding [12]. However, there remains a paucity of robust data to guide this decision. We therefore sought to systematically review and synthesize the existing data on the cardiovascular and GI risks of H2RA relative to PPI therapy in patients on DAPT for ACS or CAD.

\section{Methods}

We included all RCTs comparing H2RA to PPI therapy in patients aged $\geq 18$ years on DAPT for a minimum of 1 week for ACS or CAD indications. No restrictions were placed on concomitant therapies, comorbidities, or specific medications in either drug class. Study designs other than RCTs were excluded as were nonEnglish reports. The clinical outcomes of interest were GI complications, including GI bleeding and ulcers/erosions identified on endoscopy, and major adverse cardiovascular event (MACE). The laboratory outcome of interest was high on-treatment platelet reactivity (HTPR). Due to expected discrepancies in how these outcomes were defined between RCTs, study-specific rather than prespecified outcome criteria were used. Outcome data were included irrespective of whether they were primary/main or secondary outcome measures in the original studies. Studies with more than 2 arms (i.e., including an additional medication or a placebo group) were considered, but we restricted our analysis to the comparison between H2RA and PPI. Studies that included multiple medications within the same class were combined into one category for the purpose of this analysis. Two studies $[13,14]$ had a cross-over design, sequentially testing PPIs then H2RAs in their patients' cohort. We therefore included the total number of patients in the denominator of both H2RA and PPI study groups. With regards to the search strategy, studies were identified by searching MEDLINE, EMBASE, PubMed, and Cochrane Central Register of Controlled Trials (CENTRAL). The full search strategy is available in the supplemental information section. Bibliographies of included articles and relevant review articles were also pursued to identify additional studies. All articles were independently screened by 2 reviewers (A.A. and F.D.R.) by review of article titles and abstracts prior to full-text review for study appropriateness and data collection. Discrepancies at any stage were resolved by discussion or independent adjudication (B.H.).

Quantitative data were extracted from papers included in the review using the modified standardized data extraction tool from Joanna Briggs Institute Meta-Analysis of Statistics Assessment and Review Instrument for randomized clinical trials [15]. The data extracted included authors, journal, publication year, medical condition or risk factors, sample size and calculation, ethical approval, intervention measures, drug doses, course of treatment and duration of follow-up, drug co-administration, baseline cardiac or GI disease (and differences between groups), relevant outcomes reported (clinical and/or laboratory), and statistical methods.

Studies selected for retrieval were assessed for methodological validity prior to inclusion in the review using the Cochrane Risk of Bias tool [16]. This tool assesses the following 7 domains of bias: sequence generation, allocation concealment, blinding of outcome assessment, incompleteness outcome data, selective outcome reporting, other types of biases, and funding. Studies were considered at low, high, or unclear risk in each domain.

Data from individual studies are reported separately and were pooled via meta-analysis. Effect sizes were expressed as risk ratios and reported with 95\% CI. Statistical heterogeneity was assessed using the $I^{2}$ statistic. Fixed effects models were used based on low clinical heterogeneity across studies, which was corroborated via the $I^{2}$ statistic. The risk of publication bias was visually evaluated using funnel plots; only the HTPR laboratory outcome's funnel plot was reported (online suppl. Figure; for all online suppl. material, see www.karger.com/ doi/10.1159/000489165), as there was a very small number of studies assessing GI complications and MACE outcomes, which renders their funnel plots uninterpretable.

In one study [17], authors did not report the number of patients with HTPR but reported platelet reactivity unit (PRU) data and commented that it was a normally distributed variable. 
Fig. 1. Flow diagram of included RCTs comparing PPIs to H2RAs in patients with CAD or ACS on DAPT. PPI, proton pump inhibitors; H2RA, Histamine 2 receptor antagonists; $\mathrm{CAD}$, coronary artery disease; ACS, acute coronary syndrome; DAPT, dual antiplatelet therapy; RCTs, randomized controlled trials.

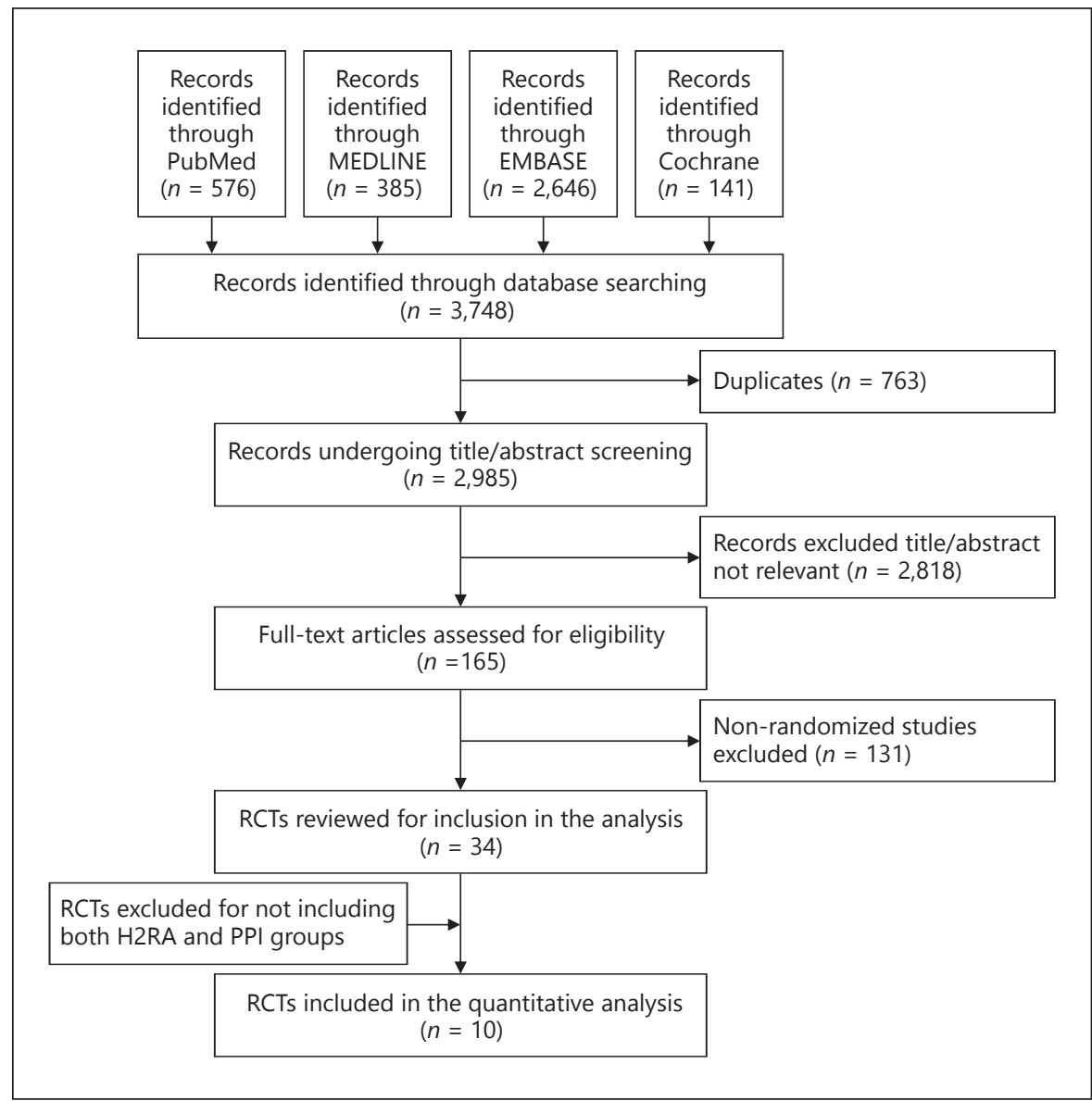

Therefore, the number of patients above the previously validated PRU value of 240 for HTPR was estimated based on the reported mean and standard deviation using the relevant $Z$-score [18]. The reporting format of this systematic review follows the Preferred Reporting Items for Systematic Reviews and MetaAnalyses Statement revised in 2009 [19]. All analyses were performed using RevMan version 5 (Cochrane Collaboration, Copenhagen, Denmark). Statistical significance was set at 0.05 (2-tailed analyses).

\section{Results}

After excluding duplicates, 2,985 articles underwent title and abstract screening, of which 165 were selected for full-text review. After excluding nonrandomized studies and studies lacking both H2RA and PPI treatment groups, 10 RCTs ultimately met inclusion criteria (Fig. 1) [9-11, $13,17,20-23]$. All included studies were published between 1980 and 2016.

Patient demographics, clinical characteristics, and outcomes are summarized separately for the main out- comes assessed (Table 1; online suppl. Tables S1-S3). The number of participants in PPI treatment groups ranged from 21 to 163 with a follow-up of 1-52 weeks. The PPIs studied included pantoprazole, esomeprazole, omeprazole, rabeprazole, and lansoprazole. The H2RA treatment groups ranged from 21 to 148 patients in size and studied famotidine (20-40 $\mathrm{mg} /$ day), ranitidine (150-300 mg/day), and cimetidine (400 mg twice daily). Most studies included patients with ACS or CAD who had recently undergone percutaneous coronary intervention with stenting on ASA and clopidogrel [9-11, 14, $20,21,23$ ]. Three studies included ACS or CAD patients more than 1 month after they had undergone percutaneous coronary intervention $[13,17,22]$. The length of DAPT was not specified in 2 studies $[9,10]$. Most studies excluded patients with recent GI bleeds or ulcers $[9,13$, 20, 21, 23]. One study excluded patients with HTPR at baseline, which was defined as adenosine diphosphateinduced platelet aggregation (ADP-PA) $>46 \%$ [10]. All other studies reporting on this outcome did not exclude patients based on baseline platelet reactivity or genetic 
Table 1. Characteristics of trials comparing PPIs to H2RAs in patients with CAD or ACS on DAPT, including outcomes assessed

\begin{tabular}{|c|c|c|c|c|c|c|c|c|}
\hline Trial, year & \multicolumn{2}{|l|}{ Comparison groups } & Population & Total & $\begin{array}{l}\text { Follow-up, } \\
\text { months }\end{array}$ & \multicolumn{3}{|c|}{ Outcomes assessed } \\
\hline $\begin{array}{l}\text { Wang et al. } \\
{[23], 2013}\end{array}$ & $\begin{array}{l}\text { Omeprazole } 40 \text { daily } \\
\text { and pantoprazole } \\
40 \text { daily }\end{array}$ & $\begin{array}{l}\text { Famotidine } \\
40 \text { mg daily }\end{array}$ & $\begin{array}{l}\text { ACS with or without stenting on ASA and } \\
\text { clopidogrel within } 30 \text { days post MI, excluding } \\
\text { prior gastritis or ulcer }\end{array}$ & 240 & 1 & + & + & 0 \\
\hline $\begin{array}{l}\mathrm{Ng} \text { et al. } \\
{[21], 2012}\end{array}$ & $\begin{array}{l}\text { Esomeprazole } \\
20 \text { mg daily }\end{array}$ & $\begin{array}{l}\text { Famotidine } \\
40 \text { mg daily }\end{array}$ & $\begin{array}{l}\text { ACS with or without stenting on ASA and } \\
\text { clopidogrel within } 30 \text { days post MI, excluding } \\
\text { known ulcer or recent GI bleed }\end{array}$ & 313 & 4.5 & + & + & 0 \\
\hline $\begin{array}{l}\text { Moceri et al. } \\
{[13], 2011}\end{array}$ & $\begin{array}{l}\text { Esmoprazole } \\
20 \text { mg daily }\end{array}$ & $\begin{array}{l}\text { Ranitidine } \\
150 \text { mg daily }\end{array}$ & $\begin{array}{l}\text { CAD patients, more than } 30 \text { days post } \\
\text { stenting on ASA and clopidogrel, excluded } \\
\text { prior ulcer or GI bleed }\end{array}$ & 21 & 1 & + & + & + \\
\hline $\begin{array}{l}\text { Parri et al. } \\
{[11], 2013}\end{array}$ & $\begin{array}{l}\text { Pantoprazole } \\
40 \text { mg daily }\end{array}$ & $\begin{array}{l}\text { Ranitidine } \\
150 \text { mg daily }\end{array}$ & $\begin{array}{l}\text { ACS with stenting on ASA and } \\
\text { clopidogrel within } 30 \text { days post MI }\end{array}$ & 105 & 1 & 0 & + & + \\
\hline $\begin{array}{l}\text { Park et al. } \\
{[10], 2013}\end{array}$ & $\begin{array}{l}\text { Rabeprazole } \\
20 \text { mg daily }\end{array}$ & $\begin{array}{l}\text { Famotidine } \\
40 \text { mg daily }\end{array}$ & $\begin{array}{l}\text { Elective CAD patients with PCI on ASA } \\
\text { and clopidogrel excluding those with } \\
\text { baseline high platelet reactivity defined as } \\
5 \mu \mathrm{M} \text { ADP-PA }>46 \%\end{array}$ & 78 & 0.5 & 0 & 0 & + \\
\hline $\begin{array}{l}\text { Pham et al. } \\
{[22], 2011}\end{array}$ & $\begin{array}{l}\text { Omeprazole } \\
40 \text { daily }\end{array}$ & $\begin{array}{l}\text { Ranitidine } \\
150 \text { bid and } \\
\text { Cimetidine } \\
400 \text { bid }\end{array}$ & $\begin{array}{l}\text { Stable CAD patients after } 1 \text { month of ASA } \\
\text { and clopidogrel }\end{array}$ & 60 & 0.33 & 0 & 0 & + \\
\hline
\end{tabular}

PPI, proton pump inhibitors; H2RA, Histamine 2 receptor antagonists; CAD, coronary artery disease; ACS, acute coronary syndrome; GI, gastrointestinal complications; MACE, major adverse cardiovascular events; HTPR, high on-treatment platelet reactivity. DAPT, dual antiplatelet therapy; ASA, Aspirin; N/A, not/applicable, outcomes not studied in trials or $p$ values not reported. PCI, percutaneous coronary intervention; +, outcomes evaluated; 0 , outcomes not evaluated.

predisposition to clopidogrel resistance $[9,11,13,14,17$, 20, 22].

The risk of bias within studies is detailed in Table 3 for all studies. Except for 4 [9, 14, 17, 24], most studies were at moderate to high risk of bias and had unclear reporting of funding sources. Individual study definitions for GI complications, MACE, and HTPR are described in online supplementary Tables S1-S3 respectively. GI complications were similarly defined, mostly including clinical or laboratory evidence of GI bleeding (hematemesis or melena) or an otherwise unexplained drop in hemoglobin $[13,23]$ with 3 studies reporting on endoscopic erosions/ulcers $[9,20,21]$. Most of the included RCTs reported MACE as a combination of death, myocardial infarction or re-infarction, stent thrombosis, stroke, and/or hospitalization for cardiovascular reasons $[11,20,21]$. Two studies differed in their MACE definitions. Moceri et al. [13] reported chest pain, heart failure, and thrombotic events (not clearly defined), while Wang et al. [23] reported in-stent restenosis on angiography for recurrent ACS. HTPR was defined based on the platelet function assay used but included 
Table 2. Results of trials comparing PPIs to H2RAs in patients with CAD or ACS on DAPT, assessing GI, MACE, and HTPR outcomes

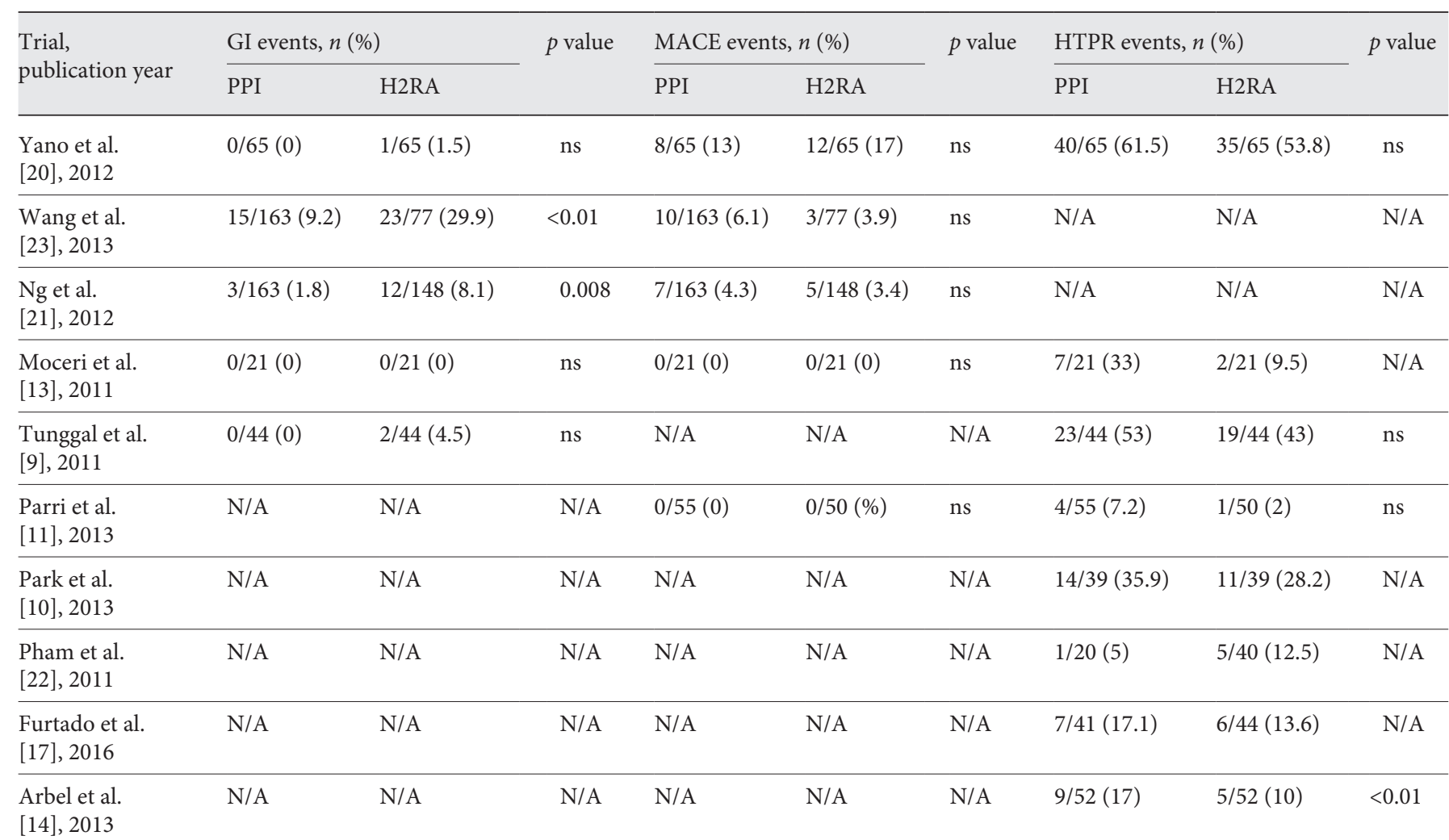

PPI, proton pump inhibitors; H2RA, Histamine 2 receptor antagonists; CAD, coronary artery disease; ACS, acute coronary syndrome; GI, gastrointestinal complications; MACE, major adverse cardiovascular events; HTPR, high on-treatment platelet reactivity; DAPT, dual antiplatelet therapy; N/A, not/applicable, outcomes not studied in trials or $p$ values not reported; ns, not significant.

Table 3. Revised cochrane collaboration's tool for quality assessment in trials comparing PPIs to H2RAs in patients with CAD or ACS on DAPT

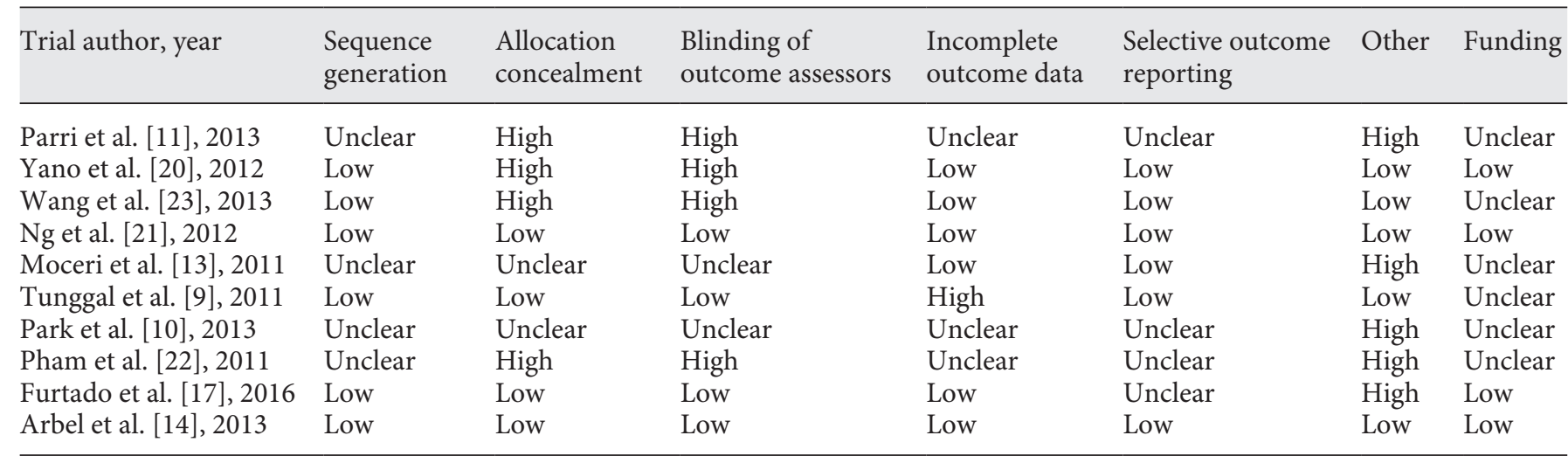

* Each criterion has been evaluated as being "high," "low," or "unclear" regarding the risk of bias following the guidelines of the cochrane collaboration's tool for assessing risk of bias in randomised trials [11]. The domains were evaluated as "unclear" when the methods used for the randomization or treatment allocation were not clearly reported.

PPI, proton pump inhibitors; H2RA, Histamine 2 receptor antagonists; CAD, coronary artery disease; ACS, acute coronary syndrome; DAPT, dual antiplatelet therapy. 


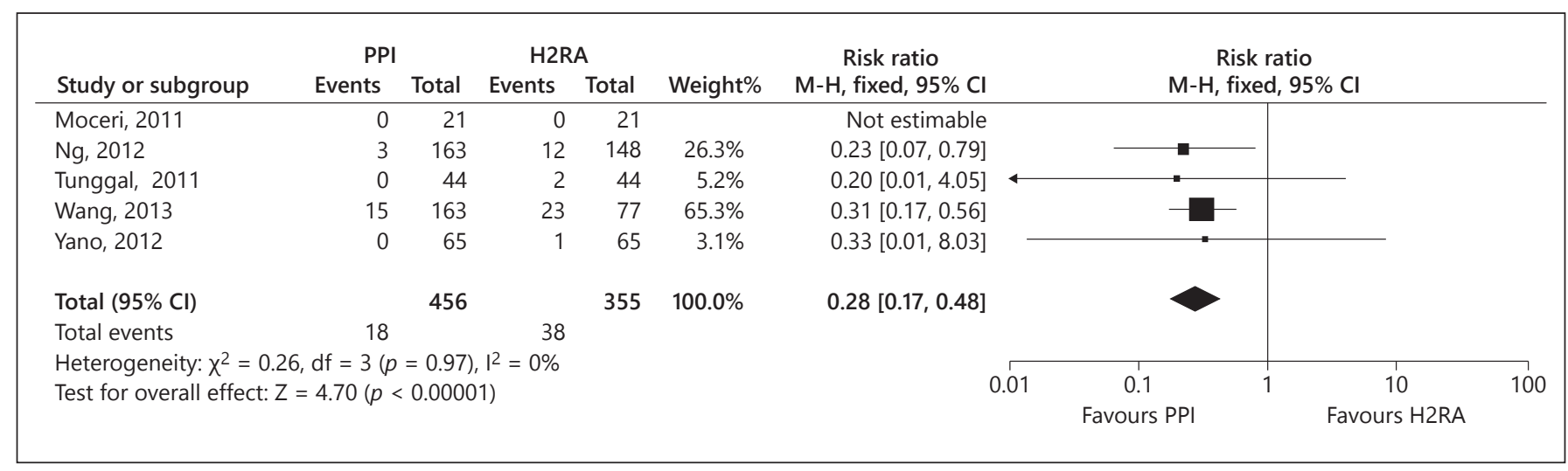

Fig. 2. Forest plot comparing H2RA versus PPI in terms of gastrointestinal complications. H2RA, Histamine 2 receptor antagonists; PPI, proton pump inhibitors.

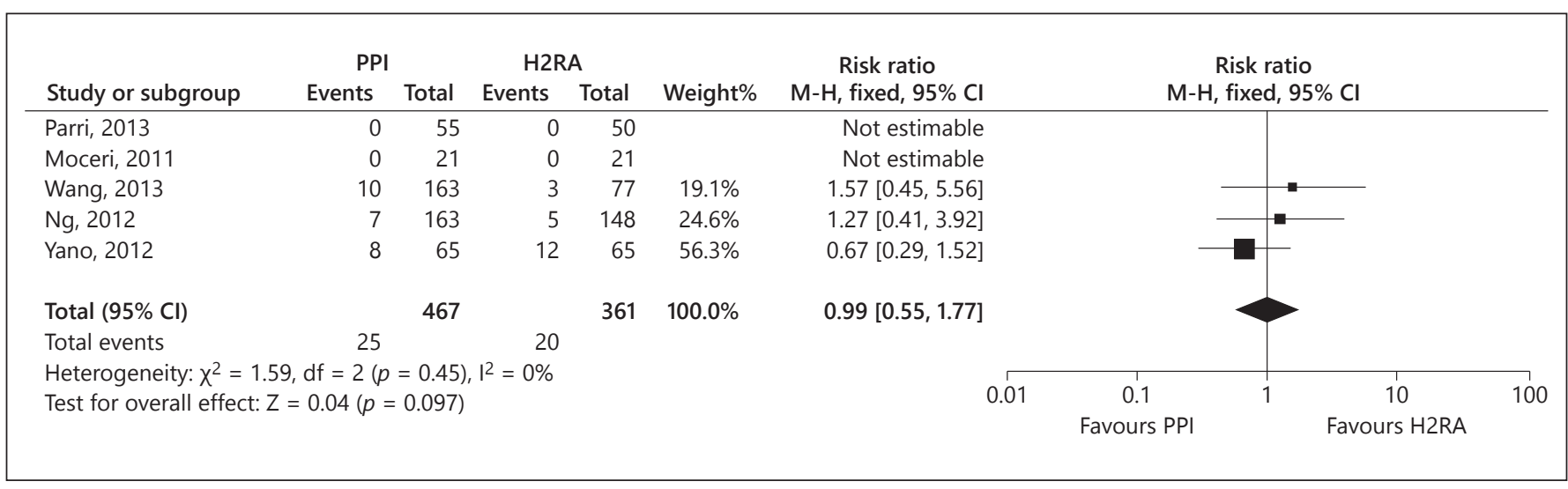

Fig. 3. Forrest plot comparing H2RA versus PPIs in terms of MACE. H2RA, Histamine 2 receptor antagonists; PPI, proton pump inhibitors; MACE, major adverse cardiovascular events.

platelet reactivity index $\geq 50 \%$ using the vasodilatorstimulated phosphoprotein assay, PRU $\geq 240$ or maximal percentage $\mathrm{PA}>50 \%$ using the VerifyNow assay (ADP-PA) $>46 \%$ using the platelet function analyzer (PFA)-100, PRU $\geq 230$ using the VerifyNow assay, or an ADP-maximal aggregation $\geq 70 \%$ using light transmittance aggregometry $[10,11,13,14,17,20-22,25]$. The above platelet function tests and selected thresholds have been validated and correlated with MACE in multiple previous studies [26].

Clinical and statistical inter-study heterogeneity was low for all outcomes assessed $\left(I^{2}=0 \%, p>0.05\right.$ for all). Fixed effects meta-analysis suggested that PPI therapy was superior to H2RA for preventing GI complications (OR 0.28, 95\% CI 0.17-0.48, $p<0.001$; Table 2; Fig. 2). The incidence of MACE did not differ between PPI and H2RA treatment groups (OR 0.99, 95\%
CI 0.55-1.77, $p=0.97$; Table 2; Fig. 3). However, PPI treatment was associated with a higher risk of having HTPR (OR 1.28, 95\% CI 1.03-1.60, $p=0.03$; Table 2; Fig. 4).

\section{Discussion}

Bleeding, commonly of GI source, constitutes the most common adverse event observed in patients admitted with ACS, exceeding the individual risks of heart failure, cardiogenic shock, or death [27]. Bleeding in ACS patients has been consistently linked with a worse prognosis, including a $60 \%$ increase in mortality when major bleeding has occurred [28]. PPIs, being recognized as powerful gastroprotective agents, are typically selected as the agents of choice to prevent adverse GI 


\begin{tabular}{|c|c|c|c|c|c|c|c|c|c|}
\hline \multirow[b]{2}{*}{ Study or subgroup } & \multicolumn{2}{|c|}{ PPI } & \multicolumn{2}{|c|}{ H2RA } & \multirow[b]{2}{*}{ Weight\% } & \multirow{2}{*}{$\begin{array}{c}\text { Risk ratio } \\
\mathrm{M}-\mathrm{H} \text {, fixed, } 95 \% \mathrm{Cl}\end{array}$} & \multirow{2}{*}{\multicolumn{2}{|c|}{$\begin{array}{c}\text { Risk ratio } \\
\mathrm{M}-\mathrm{H} \text {, fixed, } 95 \% \mathrm{Cl}\end{array}$}} & \\
\hline & Events & Total & Events & Total & & & & & \\
\hline Yano, 2012 & 40 & 65 & 35 & 65 & $42.6 \%$ & $1.14[0.85,1.54]$ & & -7 & \\
\hline Tunggal, 2011 & 23 & 44 & 19 & 44 & $23.1 \%$ & $0.21[0.78,1.88]$ & & - & \\
\hline Pham, 2011 & 1 & 20 & 5 & 40 & $4.1 \%$ & $0.40[0.05,3.20]$ & & & \\
\hline Parri, 2013 & 4 & 55 & 1 & 50 & $1.3 \%$ & $3.64[0.42,31.46]$ & &. & \\
\hline Park, 2013 & 14 & 39 & 11 & 39 & $13.4 \%$ & $1.27[0.66,2.45]$ & & $\square$ & \\
\hline Moceri, 2011 & 7 & 21 & 3 & 21 & $2.4 \%$ & $3.50[0.82,14.93]$ & & $=$ & \\
\hline Furtado, 2016 & 7 & 41 & 6 & 44 & $7.0 \%$ & $1.25[0.46,3.42]$ & & - & \\
\hline Arbel, 2013 & 9 & 52 & 5 & 52 & $6.1 \%$ & $1.80[0.65,5.01]$ & & $\rightarrow$ & \\
\hline Total $(95 \% \mathrm{Cl})$ & & 337 & & 355 & $100.0 \%$ & $1.28[1.03,1.60]$ & & $\gamma$ & \\
\hline Total events & 105 & & 84 & & & & \multicolumn{3}{|c|}{$\begin{array}{l}\text { Total events } \\
\text { Heterogeneity: } x^{2}=5.02, d f=7(p=0.66), l^{2}=0 \%\end{array}$} \\
\hline \multicolumn{6}{|c|}{ Test for overall effect: $Z=2.19(p=0.03)$} & 0.01 & $\begin{array}{c}0.1 \\
\text { Favours PPI }\end{array}$ & $\begin{array}{c}10 \\
\text { Favours H2RA }\end{array}$ & 100 \\
\hline
\end{tabular}

Fig. 4. Forest plot comparing H2RA versus PPI in terms of high on-treatment platelet reactivity. H2RA, Histamine 2 receptor antagonists; PPI, proton pump inhibitors.

complications [6-8]; however, their association with multiple adverse events and the suggestion that they may lessen the benefits of clopidogrel have raised concerns. Thus, we set out to compare the efficacy (reduction in GI complications) and safety (MACE risk) of 2 gastroprotective regimens, namely, PPIs and H2RAs. Based on our systematic review and meta-analysis, PPIs were more efficacious and demonstrated equivalent safety compared to H2RAs based on the 10 included randomized clinical trials.

Consistent with previous studies [29, 30], we concluded that PPIs were superior to H2RAs in terms of gastroprotection; reducing the risk of GI complications in patients on DAPT. However, we found that this was at the expense of weakened platelet inhibition - a finding that increases concerns of increased risk of MACE. As PPIs inhibit hepatic cytochrome P450, which is required for the activation of clopidogrel into its active metabolite, PPIs have been shown to decrease the platelet inhibitory effect of clopidogrel [31,32]. On the other hand, H2RAs (except for cimetidine, which is a cytochrome 450 inhibitor) are considered relatively safer and are less likely to pose significant drug-drug interaction problems with clopidogrel [33]. Notably, the attenuated platelet inhibition did not translate into increased MACE in our analysis; however, the small sample size and low number of events in available RCTs render this effect estimate imprecise and small differences in event rates could exist.

Overall, our analysis supports current clinical practice guidelines suggesting that clinicians should balance the risks of less effective platelet inhibition and theoretical risk of MACE against the benefits of gastroprotection when prescribing acid-suppressive medications in patients on DAPT with risk factors for GI bleeding [12, 34]. However, important gaps in our knowledge remain including relative efficacy of these regimens in patients on newer P2Y12 agents or patients on aspirin and an anticoagulant. Most recently, the COMPASS trial reported benefits of dual-pathway inhibition with aspirin and rivaroxaban in patients with stable CAD. While definitive benefit of the combination therapy was demonstrated in terms of MACE [3], we await results from the GI protection arm of the study comparing pantoparazole to placebo for GI protection. This question will likely become of greater clinical importance, considering the growing use of NOACs in CAD patients [35], which are estimated to account for 5-8\% of patients referred for elective or urgent revascularization [36].

Certainly, our study is not without limitations. While the number of studies was adequate, the relative size and low event rates reported therein limited our power to detect clinically important differences in MACE. While the point estimate suggests safety of a PPI strategy, important clinical differences could exist. Furthermore, the populations studied were mainly ACS patients and CAD patients post stenting on clopidogrel, which may not be generalizable to stable CAD patients without recent stenting and to patients on newer P2Y12 inhibitors, namely, prasugrel and ticagrelor. Finally, the tests used and definitions to determine HTPR varied between studies. While there is undoubtedly an impact on platelet reactiv- 
ity in clopidogrel-treated patients with PPIs, the magnitude and clinical impact of these differences remain difficult to infer.

In conclusion, PPIs were superior to H2RAs for reducing the risk of GI complications in patients on DAPT, specifically with clopidogrel. However, PPI therapy was associated with an increased risk of HTPR with no demonstrable increased risk of MACE. There- fore, in patients being treated with DAPT deemed at risk for GI bleeding, PPIs should be utilized for gastroprotection.

\section{Disclosure Statement}

The authors have no conflicts of interest to declare.

\section{References}

1 O'Gara PT, Kushner FG, Ascheim DD, Casey DE Jr, Chung MK, de Lemos JA, Ettinger SM, Fang JC, Fesmire FM, Franklin BA, Granger CB, Krumholz HM, Linderbaum JA, Morrow DA, Newby LK, Ornato JP, Ou N, Radford MJ, Tamis-Holland JE, Tommaso CL, Tracy CM, Woo YJ, Zhao DX; American College of Cardiology Foundation; American Heart Association Task Force on Practice Guidelines; American College of Emergency Physicians; Society for Cardiovascular Angiography and Interventions: 2013 ACCF/AHA guideline for the management of ST-elevation myocardial infarction: executive summary: a report of the American College of Cardiology Foundation/American Heart Association Task Force on Practice Guidelines: developed in collaboration with the American College of Emergency Physicians and Society for Cardiovascular Angiography and Interventions. Catheter Cardiovasc Interv2013;82:E1-E27.

2 Sheikh Rezaei S, Geroldinger A, Heinze G, Reichardt B, Wolzt M: Clopidogrel, prasugrel, or ticagrelor use and clinical outcome in patients with acute coronary syndrome: a nationwide long-term registry analysis from 2009 to 2014. Int J Cardiol 2017;235:61-66.

3 Eikelboom JW, Connolly SJ, Bosch J, Dagenais GR, Hart RG, Shestakovska O, Diaz R, Alings M, Lonn EM, Anand SS, Widimsky P, Hori M, Avezum A, Piegas LS, Branch KRH, Probstfield J, Bhatt DL, Zhu J, Liang Y, Maggioni AP, Lopez-Jaramillo P, O’Donnell M, Kakkar AK, Fox KAA, Parkhomenko AN, Ertl G, Stork S, Keltai M, Ryden L, Pogosova N, Dans AL, Lanas F, Commerford PJ, TorpPedersen C, Guzik TJ, Verhamme PB, Vinereanu D, Kim JH, Tonkin AM, Lewis BS, Felix C, Yusoff K, Steg PG, Metsarinne KP, Cook Bruns N, Misselwitz F, Chen E, Leong D, Yusuf S; COMPASS Investigators: Rivaroxaban with or without aspirin in stable cardiovascular disease. N Engl J Med 2017;377:13191330.

4 Juurlink DN, Gomes T, Ko DT, Szmitko PE, Austin PC, Tu JV, Henry DA, Kopp A, Mamdani MM: A population-based study of the drug interaction between proton pump inhibitors and clopidogrel. CMAJ 2009;180:713-718.

5 Bhatt DL, Cryer BL, Contant CF, Cohen M,
Lanas A, Schnitzer TJ, Shook TL, Lapuerta P, Goldsmith MA, Laine L, Scirica BM, Murphy SA, Cannon CP: Clopidogrel with or without omeprazole in coronary artery disease. $\mathrm{N}$ Engl J Med 2010;363:1909-1917.

6 Kwok CS, Arthur AK, Anibueze CI, Singh S, Cavallazzi R, Loke YK: Risk of Clostridium difficile infection with acid suppressing drugs and antibiotics: meta-analysis. Am J Gastroenterol 2012;107:1011-1019.

7 Eom CS, Jeon CY, Lim JW, Cho EG, Park SM, Lee KS: Use of acid-suppressive drugs and risk of pneumonia: a systematic review and meta-analysis. CMAJ 2011;183:310-319.

8 Hammond DA, Kathe N, Shah A, Martin BC: Cost-effectiveness of histamine ${ }_{2}$ receptor antagonists versus proton pump inhibitors for stress ulcer prophylaxis in critically Ill patients. Pharmacotherapy 2017;37:43-53.

9 Tunggal P, Ng FH, Lam KF, Chan FK, Lau YK: Effect of esomeprazole versus famotidine on platelet inhibition by clopidogrel: a double-blind, randomized trial. Am Heart J 2011; 162:870-874.

10 Park YH, Koh JS, Kwak CH, Hwang JY: Effect of rabeprazole versus famotidine on platelet inhibition in patients with normal clopidogrel responsiveness: result of the ACCEL-PROTECT randomized study. Eur Heart J 2013; 34:4910.

11 Parri MS, Gianetti J, Dushpanova A, Della Pina F, Saracini C, Marcucci R, Giusti B, Berti S: Pantoprazole significantly interferes with antiplatelet effect of clopidogrel: results of a pilot randomized trial. Int J Cardiol 2013;167: 2177-2181.

12 Tanguay JF, Bell AD, Ackman ML, Bauer RD, Cartier R, Chan WS, Douketis J, Roussin A, Schnell G, Verma S, Wong G, Mehta SR; Canadian Cardiovascular Society: Focused 2012 update of the Canadian Cardiovascular Society guidelines for the use of antiplatelet therapy. Can J Cardiol 2013;29: 1334-1345.

13 Moceri P, Doyen D, Cerboni P, Ferrari E: Doubling the dose of clopidogrel restores the loss of antiplatelet effect induced by esomeprazole. Thromb Res 2011;128:458-462.

14 Arbel Y, Birati EY, Finkelstein A, Halkin A, Kletzel H, Abramowitz Y, Berliner S, Deutsch V, Herz I, Keren G, Banai S: Platelet inhibi- tory effect of clopidogrel in patients treated with omeprazole, pantoprazole, and famotidine: a prospective, randomized, crossover study. Clin Cardiol 2013;36:342-346.

15 Pearson A: Joanna Briggs Institute Reviewers' Manual: 2014 Edition, ed 2014. Australia, The Joanna Briggs Institute, 2014.

16 Higgins JP, Altman DG, Gotzsche PC, Juni P, Moher D, Oxman AD, Savovic J, Schulz KF, Weeks L, Sterne JA; Cochrane Bias Methods Group; Cochrane Statistical Methods Group: The cochrane collaboration's tool for assessing risk of bias in randomised trials. BMJ 2011;343:d5928.

17 Furtado RH, Giugliano RP, Strunz CM, Filho CC, Ramires JA, Filho RK, Neto PA, Pereira AC, Rocha TR, Freire BT, D’Amico EA, Nicolau JC: Drug interaction between clopidogrel and ranitidine or omeprazole in stable coronary artery disease: a doublebBlind, double dummy, randomized study. Am J Cardiovasc Drugs 2016;16:275-284.

18 Patti G, Nusca A, Mangiacapra F, Gatto L, D’Ambrosio A, Di Sciascio G: Point-of-care measurement of clopidogrel responsiveness predicts clinical outcome in patients undergoing percutaneous coronary intervention results of the ARMYDA-PRO (Antiplatelet therapy for Reduction of MYocardial Damage during Angioplasty-Platelet Reactivity Predicts Outcome) study. J Am Coll Cardiol 2008;52:1128-1133.

19 Urrutia G, Bonfill X: [PRISMA declaration: a proposal to improve the publication of systematic reviews and meta-analyses]. Med Clin (Barc) 2010;135:507-511.

20 Yano H, Tsukahara K, Morita S, Endo T, Sugano T, Hibi K, Himeno H, Fukui K, Umemura S, Kimura K: Influence of omeprazole and famotidine on the antiplatelet effects of clopidogrel in addition to aspirin in patients with acute coronary syndromes: a prospective, randomized, multicenter study. Circ J 2012; 76:2673-2680.

21 Ng FH, Tunggal P, Chu WM, Lam KF, Li A, Chan K, Lau YK, Kng C, Keung KK, Kwan A, Wong BC: Esomeprazole compared with famotidine in the prevention of upper gastrointestinal bleeding in patients with acute coronary syndrome or myocardial infarction. Am J Gastroenterol 2012;107:389-396. 
22 Pham JP, Ueno M, Tello-Montoliu A, Ferreiro JL, Tomasello SD, Dharmashankar K, Kodali M, Seecheran N, Capodanno D, Desai B, Bass TA, Angiolillo DJ: Impact of gastric acid-suppressing therapies on platelet reactivity in patients with coronary artery disease treated with clopidogrel: results of a pharmacodynamic study. J Am Coll Cardiol 2011;58:1396-1398.

23 Wang Z, Cai J, Chen M, Wan X: Influence of different proton pump inhibitors on platelet function in acute myocardial infarction patients receiving clopidogrel treatment after percutaneous coronary intervention. Biomed Res 2013;24:453-457.

24 Kimura BJ, Amundson SA, Phan JN, Agan DL, Shaw DJ: Observations during development of an internal medicine residency training program in cardiovascular limited ultrasound examination. J Hosp Med 2012;7:537542.

25 Bonello L, Tantry US, Marcucci R, Blindt R, Angiolillo DJ, Becker R, Bhatt DL, Cattaneo M, Collet JP, Cuisset T, Gachet C, Montalescot G, Jennings LK, Kereiakes D, Sibbing D, Trenk D, Van Werkum JW, Paganelli F, Price MJ, Waksman R, Gurbel PA; Working Group on High On-Treatment Platelet Reactivity: Consensus and future directions on the definition of high on-treatment platelet reactivity to adenosine diphosphate. J Am Coll Cardiol 2010;56:919-933.

26 Paniccia R, Priora R, Liotta AA, Abbate R: Platelet function tests: a comparative review.
Vasc Health Risk Manag 2015;11:133-148.

27 Moscucci M, Fox KA, Cannon CP, Klein W, Lopez-Sendon J, Montalescot G, White K, Goldberg RJ: Predictors of major bleeding in acute coronary syndromes: the Global Registry of Acute Coronary Events (GRACE). Eur Heart J 2003;24:1815-1823.

28 Fitchett D: The impact of bleeding in patients with acute coronary syndromes: how to optimize the benefits of treatment and minimize the risk. Can J Cardiol 2007;23:663-671.

29 Lin KJ, Hernandez-Diaz S, Garcia Rodriguez LA: Acid suppressants reduce risk of gastrointestinal bleeding in patients on antithrombotic or anti-inflammatory therapy. Gastroenterology 2011;141:71-79.

30 Tamura A, Murakami K, Kadota J; OITA-GF Study 2 Investigators: Prevalence of gastroduodenal ulcers/erosions in patients taking low-dose aspirin with either $15 \mathrm{mg} /$ day of lansoprazole or $40 \mathrm{mg} /$ day of famotidine: the OITA-GF study 2. BMC Res Notes 2013; 6:116.

31 Sherwood MW, Melloni C, Jones WS, Washam JB, Hasselblad V, Dolor RJ: Individual proton pump inhibitors and outcomes in patients with coronary artery disease on dual antiplatelet rtherapy: a systematic review. J Am Heart Assoc 2015;4:e002245.

32 Weisz G, Smilowitz NR, Kirtane AJ, Rinaldi MJ, Parvataneni R, Xu K, Stuckey TD, Maehara A, Witzenbichler B, Neumann FJ, Metzger DC, Henry TD, Cox DA, Duffy PL, Brodie BR, Mazzaferri EL Jr, Mehran R, Stone
GW: Proton pump inhibitors, platelet reactivity, and cardiovascular outcomes after drugeluting stents in clopidogrel-treated patients: the ADAPT-DES study. Circ Cardiovasc Interv 2015;8:e001952.

33 Siller-Matula JM, Trenk D, Krahenbuhl S, Michelson AD, Delle-Karth G: Clinical implications of drug-drug interactions with P2Y12 receptor inhibitors. J Thromb Haemost 2014; 12:2-13.

34 Abraham NS, Hlatky MA, Antman EM, Bhatt DL, Bjorkman DJ, Clark CB, Furberg CD, Johnson DA, Kahi CJ, Laine L, Mahaffey KW, Quigley EM, Scheiman J, Sperling LS, Tomaselli GF; ACCF/ACG/AHA: ACCF/ACG/ AHA 2010 expert consensus document on the concomitant use of proton pump inhibitors and thienopyridines: a focused update of the ACCF/ACG/AHA 2008 expert consensus document on reducing the gastrointestinal risks of antiplatelet therapy and NSAID use: a report of the American College of Cardiology Foundation Task Force on Expert Consensus Documents. Circulation 2010;122:2619-2633.

35 Barnes GD, Lucas E, Alexander GC, Goldberger ZD: National trends in ambulatory oral anticoagulant use. Am J Med 2015;128:13001305.e1302.

36 Rubboli A, Faxon DP, Juhani Airaksinen KE, Schlitt A, Marin F, Bhatt DL, Lip GY: The optimal management of patients on oral anticoagulation undergoing coronary artery stenting. The 10th anniversary overview. Thromb Haemost 2014;112:1080-1087. 